\title{
Alterations in left ventricular function in normal man on exposure to high altitude $(3658 \mathrm{~m})$
}

\author{
V. BALASUBRAMANIAN, O. P. MATHEW, S. C. TIWARI, A. BEHL, \\ S. C. SHARMA, AND R. S. HOON
}

From The Stress Test and Noninvasive Laboratory, Army Hospital, Delhi Cantt, New Delhi 110010, India

SUMMARY Left ventricular function was estimated by noninvasive methods in 83 normal volunteers at sea level, at an altitude of $3658 \mathrm{~m}$ for 10 days, and on return to sea level. Of these subjects, 50 reached high altitude by air in 55 minutes and the rest by road in 6 hours. Controls comprised 56 permanent residents of high altitude and 59 lowlanders resident at high altitudes for 120 to 180 days. Simultaneous recording of electrocardiogram, phonocardiogram, carotid pulse, and first derivative of electrical impedance cardiogram yielded data in respect of pre-ejection period (PEP), left ventricular ejection time (LVET), PEP/LVET ratio, RZ interval, contractility index $\left(\frac{\mathrm{dZ} / \mathrm{dt}}{\mathrm{RZ}}\right)$, stroke index, and cardiac index. A statistically significant reduction of stroke index, cardiac index, and depression of all indices of left ventricular function was observed from the second day of induction to high altitude despite increased urinary catecholamine excretion. On return to sea level all the values returned to normal by the third day. Permanent residents of high altitude had normal left ventricular function and temporary residents a moderate depression. These findings suggest that left ventricular dysfunction occurs on induction to high altitude.

Accurate delineation of the pathophysiological alterations after subjects have been at high altitudes has interested research workers since the early years of this century (Grollman, 1930; Asmussen and Consolazio, 1941; Hultgren et al., 1964; Menon, 1965; Singh et al., 1965; Banchero et al., 1966; Klausen, 1966; Alexander et al., 1967; Hartley et al., 1967; Hartley, 1971; Roy et al., 1974; Sime et al., 1974; Balasubramanian et al., 1975; Hoon et al., 1977a, b, c). Hostile environmental conditions and limitations of the sample size caused by logistic problems and the traumatic nature of the investigations have been the main deterrents. Wide variations in results have been common. One of the classical examples is thealteration of stroke volume on high altitude induction. Published reports show results ranging from an increase to a distinct decrease (Grollman, 1930; Asmussen and Consolazio, 1941; Klausen, 1966; Vogel et al., 1967; Sime et al., 1974; Vogel et al., 1974; Hoon et al., 1977a). Similarly, controversy continues as to whether or not left ventricular dysfunction occurs at high altitude (Hultgren et al.,

Received for publication 21 June 1977
1964; Menon, 1965; Vogel et al., 1967; Moret et al., 1972). The answer to this question is of immense practical application in the prevention and management of altitude illnesses.

Moret et al. (1972) and Badeer (1973) felt that left ventricular dysfunction did not occur on acute exposure to high altitude. Vogel et al. (1967) also felt that left ventricular function was unaltered at high altitude. Kowalsky and Anthony (1972) subjected volunteers to a short term exposure to simulated hypoxia and observed an improvement in myocardial function. They attributed it to increased catecholamine secretion. Alexander et al. (1967), however, attributed depression of myocardial function as a dominant aetiological factor in the causation of reduced cardiac output at altitude.

The last decade has witnessed tremendous advances in noninvasive diagnostic methods in cardiac disease, and a large number of reliable techniques to assess left ventricular function have become available. Systolic time intervals are one of the procedures to be so recognised (Weissler et al., 1968, 1969; Aronow, 1970; Kumar and Spodick, 1970; Weissler and Schoenfeld, 1970; Lindquist et al., 1973; Quarry-Pigott et al., 1973; Lewis et al., 
1974; Weissler, 1974; Zoneraich, 1974; Lewis, 1975; Chung, 1976; Spodick and Lance, 1976; Weissler, 1976). In an earlier study we estimated systolic time intervals in 20 volunteers exposed to high altitude and reported a significant reduction in left ventricular function (Balasubramanian et al., 1975). The present report covers the investigation of a larger number of measurements in a bigger group and incorporates studies on return to sea level also.

\section{Subjects and methods}

\section{SUBJECTS}

The subjects consisted of 198 normal healthy male volunteers 20 to 35 years of age. All of them were trained persons and none of them were athletes. All groups were comparable in respect of height, weight, physical training, and dietary habits.

They were studied in the following groups-

Group $A: 50$ subjects born and brought up at an altitude of less than $1000 \mathrm{~m}$ and who had never visited higher altitudes in their life (lowlanders). These volunteers were taken to high altitude by air.

Group B: 33 subjects similar to group A reached high altitude by road in 6 hours.

Group C: 59 subjects were basically lowlanders but had stayed at high altitude continuously for 120 to 180 days preceding the study.

Group D: 56 subjects comparable in respect of height, weight, other anthropometric measurements, and physical training to groups $A, B$, and C, but who were born and brought up at altitudes above $3500 \mathrm{~m}$. They had never visited altitudes below $1000 \mathrm{~m}$.

\section{STUDY PROCEDURE}

The subjects of group A were initially studied at a temperature controlled laboratory $\left(26+2^{\circ} \mathrm{C}\right)$ at $198 \mathrm{~m}$ above sea level (henceforth called sea level) to determine baseline data. They were taken to an altitude of $3658 \mathrm{~m}$ by a pressurised aircraft in 55 minutes. At that altitude they were housed in a centrally heated hospital kept at $26 \pm 2{ }^{\circ} \mathrm{C}$ throughout the study. Smoking, alcohol consumption, and drugs were not allowed during the study. Serial estimations were made at 0 to 4 hours, 5 to 8 hours, second, third, fourth, fifth, and tenth day of arrival at high altitude. They were then returned by air to the sea level station, and studies carried out immediately on arrival, and on the second and the third days of return.

The subjects of group B were studied at sea level and reached the altitude of 3658 by road travel in 6 hours. Serial study was conducted at 18 to 20 hours of arrival, on the second, third, fourth, fifth, and tenth days at high altitude. They returned to sea level by road and studies were carried out on the second and third day of return to sea level. Groups $\mathrm{C}$ and $\mathrm{D}$ were studied once at high altitude $(3658 \mathrm{~m})$.

\section{TECHNIQUES}

As the study procedure demanded rapid recording of physiological values repetitively, conventional systolic time intervals, stroke index, and other measures of myocardial function obtained by electrical impedance plethysmography were selected as the data of choice. Simultaneous recording of electrocardiogram, phonocardiogram, and first derivative of thoracic electrical impedance plethysmogram $(\mathrm{dZ} / \mathrm{dt})$ were obtained on a direct writing three-channel recorder at a paper speed of 100 $\mathrm{mm} / \mathrm{s}$. Carotid pulse, electrocardiogram, and phonocardiogram were similarly recorded.

\section{Technique of recording}

All recordings (at sea level and at altitude) were obtained in the supine position in a quiet laboratory kept at $26 \pm 2{ }^{\circ} \mathrm{C}$. All subjects rested at least 30 minutes before each recording. All data were obtained between 9 am and 11.45 am in the postabsorptive state (except for 0 to 4 hours and 5 to 8 hours recording at altitude of group A. The former was made between $9.30 \mathrm{am}$ and $1.30 \mathrm{pm}$ and the latter from $1.30 \mathrm{pm}$ to $5.30 \mathrm{pm}$ ).

\section{Electrical impedance cardiography}

Two pairs of silver-coated copper mesh strips bonded at a distance of $5 \mathrm{~cm}$ to a neoprene belt were used as the tetrapolar circular lead system. The upper pair of electrodes was applied around the neck (above and below the cricoid cartilage), the lower pair at the level of the xiphisternum and $5 \mathrm{~cm}$ distal to it (Fig. 1). Noncorrosive electrolyte cream was used to ensure good skin contact. The electrode sites were marked with indelible ink during the baseline study to ensure application at the same site

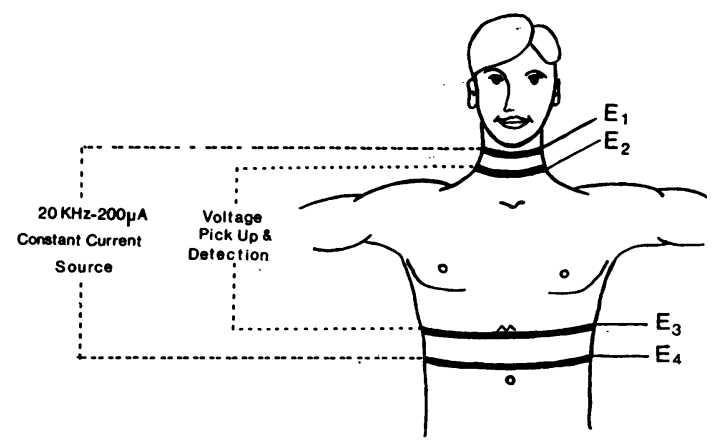

Fig. 1 Tetrapolar circular lead system used in electrical impedance cardiography. 
during subsequent studies. The patient was connected to a custom built digital impedance plethysmograph by a four core shielded patient cable. The instrument passed a sinusoidal alternating current of $20 \mathrm{kHz} 200 \mu \mathrm{A}$ RMS across the outer electrodes $E_{1}$ and $E_{4}$. The inner pair of electrodes $E_{2}$ and $E_{3}$ picked up the instantaneous impedance changes caused by the cardiac cycle and fed it into the plethysmograph (Balasubramanian and Hoon, 1975). The signal was processed, amplified, differentiated, and fed into the multichannel recorder to derive the $\mathrm{dZ} / \mathrm{dt}$ wave form. A calibration signal of $1 \mathrm{ohm} / \mathrm{s}$ was recorded before each tracing to calculate the amplitude of $\mathrm{dZ} / \mathrm{dt}$ wave form. The electrocardiogram was picked up from the outer electrodes $\mathrm{E}_{1}$ and $\mathrm{E}_{4}$ and the phonocardiogram by a high fidelity dynamic microphone situated at the best site to record the aortic closure clearly (Fig. 2). All recordings were made at comfortable end expiration to eliminate respiratory artefacts and base-
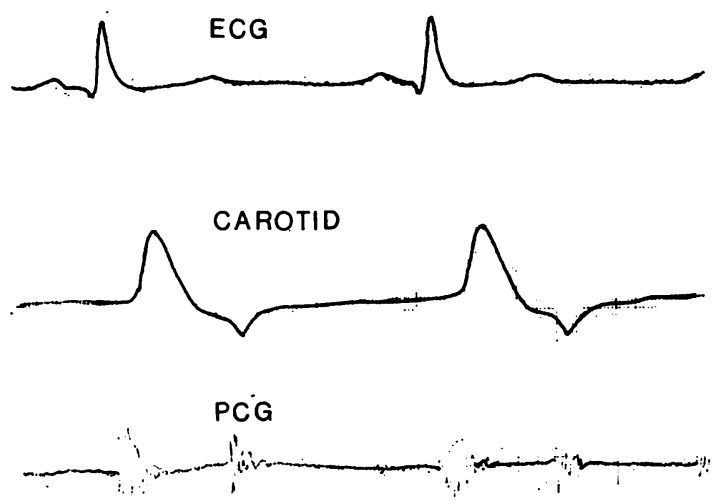

Fig. 3 Simultaneous recording of electrocardiogram, carotid pulse, and phonocardiogram at a paper speed of $100 \mathrm{~mm} / \mathrm{s}$.
Fig. 2 Simultaneous recording of electrocardiogram, first derivative of impedance cardiogram $(d Z / d t)$, and phonocardiogram at a paper speed of 100 $\mathrm{mm} / \mathrm{s}$.

line instability. A minimum of 10 complexes was recorded and 5 consecutive complexes were used for data analysis.

Another set of recordings comprising electrocardiogram, phonocardiogram, and carotid pulse using a crystal transducer (APT 102) was similarly obtained (Fig. 3).

The following were calculated (Fig. 4).

(a) Heart rate: obtained from the $\mathrm{RR}$ interval.

(b) Electromechanical systole $\left(Q S_{2}\right)$ : the duration in milliseconds from the earliest point of QRS complex to the first high frequency component of aortic closure.

(c) Left ventricular ejection time (LVET): the duration in milliseconds from the onset of the carotid wave form to the nadir of the dicrotic notch.

(d) Pre-ejection period (PEP): obtained by deducting LVET from $\mathrm{QS}_{2}$.

(e) PEP/LVET ratio.

(f) $R Z$ interval: the duration in milliseconds from the peak of the $R$ wave of the electrocardiogram to the peak of the $\mathrm{dZ} / \mathrm{dt}$ wave form.

(g) Contractility index: obtained by the formula $(\mathrm{dZ} / \mathrm{dt}) \mathrm{min} / \mathrm{RZ}:(\mathrm{dZ} / \mathrm{dt}) \mathrm{min}$ being the amplitude of the wave form in ohms/s.

The values were corrected for the heart rate by using the following regression equations (Lindquist, et al., 1973)

VET I $=1.42 \mathrm{HR}+$ observed value

PEP I $=0.44 \mathrm{HR}+$ observed value

RZ I $=0.76 \mathrm{HR}+$ observed value

(HR = heart rate, $I$ denotes index corrected for HR)

PEP/LVET and $\frac{\mathrm{dZ} / \mathrm{dt}}{\mathrm{RZ}}$ were obtained from the uncorrected values.

(h) Stroke Volume $(S V)$ : calculated by the formula 


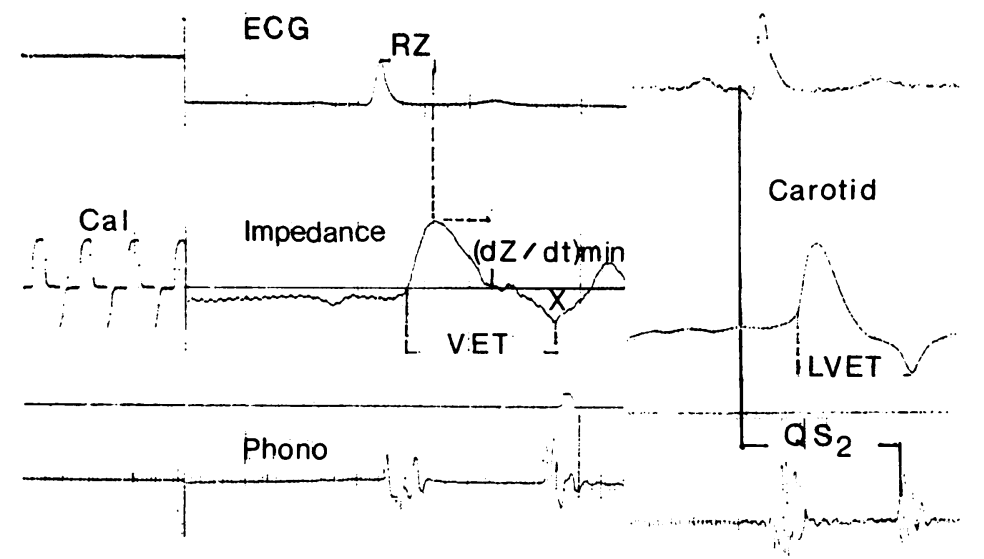

Fig. 4 Simultaneous recording of electrocardiogram, phonocardiogram, $d Z / d t$, and carotid pulse to show the parameters calculated. The amplitude of the $d Z / d t$ waveform is calculated from the peak of the $d Z / d t$ to the zero reference line. The contractility index is obtained by dividing the $d Z / d t$ amplitude in ohms/s by the $R Z$ interval in seconds.

$\mathrm{SV}=\mathrm{p} \times\left(\frac{\mathrm{L}}{\mathrm{Zo}_{\mathrm{o}}}\right)^{2} \times \mathrm{VET} \times(\mathrm{dZ} / \mathrm{dt}) \mathrm{min}, \mathrm{p}=$ resistivity constant of blood $\left(150\right.$ at $37^{\circ} \mathrm{C}$ ) (Hill and Lowe, 1973), $\mathrm{L}=$ mean distance in $\mathrm{cm}$ between the inner electrodes, $\mathrm{Zo}=$ mean transthoracic electrical impedance in ohms, VET $=$ ventricular ejection time in seconds measured from the onset of the $\mathrm{dZ} / \mathrm{dt}$ wave form to ' $\mathrm{X}$ ' point, a clear dip synchronous with aortic closure (Fig. 4). (dZ/dt) min = amplitude of the $\mathrm{dZ} / \mathrm{dt}$ wave form in ohms/s.

Stroke index was calculated by standard nomograms. Cardiac index was obtained by multiplying stroke index by heart rate. 24 hour urinary catecholamine excretion was estimated in all subjects at sea level and on days $1,2,4$, and 10 at high altitude. Studies were done on days 1 and 4 of return to sea level (Hoon et al., 1976, 1977b).

All recordings were obtained by the same recorder and impedance plethysmograph at a constant calibration of $15 \mathrm{~mm} / \mathrm{ohm}$ per s. All values were calculated by the same group of observers to eliminate variations. The data were fed into an ICL 1904 computer and the results analysed by standard statistical methods of analysis of variance, and Student's $t$ test.

\section{Results}

HEART RATE (Tables 1 and 2)

The resting heart rate of group $A$ at sea level was $64.4 / \mathrm{min}$. On induction to high altitude no significant alteration was noticed until the second day, but a steady increase occurred which later reached $77 \cdot 2 / \mathrm{min}$ on the fifth day. On return to sea level normal rates were noted by the third day. Group B had a resting heart rate of $63.2 / \mathrm{min}$ at sea level. At 18 to 20 hours of induction to high altitude it increased to $86.7 / \mathrm{min}$. The peak value of 92.3 was observed on the second day. Returning to sea level resulted in a return to normal by the third day. Group C had a mean heart rate of $69.1 / \mathrm{min}$ and group D 56.2/min.

\section{LEFT VENTRICULAR EJECTION TIME}

Subjects of group A had a basal LVET index of 378 ms at sea level. There was no significant change in this value until the second day at altitude when it dropped to $363 \mathrm{~ms}$. Thereafter a steady decline continued until the tenth day at high altitude when $348 \mathrm{~ms}$ was recorded. A return to normal occurred on the third day of return to sea level $(368 \mathrm{~ms})$. Group B had a LVET index of $381 \mathrm{~ms}$ at sea level. Reduction to $359 \mathrm{~ms}$ was noticed on the first day, which persisted until the fifth day. On the tenth day a further reduction to $350 \mathrm{~ms}$ was observed. By the third day of return to sea level the values had increased to $373 \mathrm{~ms}$. Group C had LVET I values of $369 \mathrm{~ms}$ and group D $375 \mathrm{~ms}$, respectively.

\section{PRE-EJECTION PERIOD}

The sea level control values of PEP-I of group A was $123 \mathrm{~ms}$. The second day recording at altitude yielded a value of 126 which gradually increased to $136 \mathrm{~ms}$ on the fifth day. Reversion to a level of 123 ms was observed on the third day of return to sea level. Group B had sea level control values of 127 $\mathrm{ms}$ which increased to $133 \mathrm{~ms}$ on the first day and reached a peak of $144 \mathrm{~ms}$ on the tenth day. A mean value of $133 \mathrm{~ms}$ was obtained by the third day of return to sea level. Group $C$ had values of $126 \mathrm{~ms}$ and group D $116 \mathrm{~ms}$.

PEP/LVET RATIO ( $\times 1000)$

The mean PEP/LVET ratio of group $A$ at sea level was 337. This started to increase on arrival at high altitude and reached the maximum of 415 on the tenth day. A return to normal to 342 occurred by the third day of return to sea level. The individual 
Table 1 Serial changes in measures of myocardial function in subjects inducted to $3658 \mathrm{~m}$ by air

\begin{tabular}{|c|c|c|c|c|c|c|c|c|c|c|c|c|}
\hline Time of study & $\begin{array}{l}\text { Heart ratel } \\
\text { min }\end{array}$ & $P \star$ & $P E P P \star$ & LVET & $P$ & $P E P / L V E T$ & $P$ & $\begin{array}{l}P E P / L V E T \\
>400\end{array}$ & $\begin{array}{l}R Z \\
\text { interval }\end{array}$ & $P$ & $\frac{d Z / d t}{R Z}$ & $P$ \\
\hline Sea level & $\begin{array}{l}64 \cdot 4 \\
(1 \cdot 3)\end{array}$ & 一 & $123-$ & $\begin{array}{l}378 \\
(1 \cdot 8)\end{array}$ & - & $\begin{array}{r}337 \\
(4)\end{array}$ & 一 & Nil & $\begin{array}{l}149 \\
(1 \cdot 3)\end{array}$ & 一 & $\begin{array}{l}17 \cdot 4 \\
(0 \cdot 5)\end{array}$ & - \\
\hline \multicolumn{13}{|c|}{ High altitude induction ( 55 min by air) } \\
\hline $0-4 h$ & $\begin{array}{l}66 \cdot 9 \\
(3 \cdot 2)\end{array}$ & NS & $\underset{(1 \cdot 1)}{124} \mathrm{NS}$ & $\begin{array}{l}370 \\
(2 \cdot 0)\end{array}$ & NS & $\begin{array}{r}345 \\
(4)\end{array}$ & NS & 1 & $\begin{array}{l}150 \\
(1 \cdot 4)\end{array}$ & NS & $\begin{array}{l}15 \cdot 9 \\
(0 \cdot 3)\end{array}$ & $<0.01$ \\
\hline $5-8 \mathrm{~h}$ & $\begin{array}{l}67 \cdot 0 \\
(1 \cdot 4)\end{array}$ & NS & $\begin{array}{c}125 \mathrm{NS} \\
(1 \cdot 2)\end{array}$ & $\begin{array}{r}369 \\
(1.8)\end{array}$ & NS & $\begin{array}{c}352 \\
(5)\end{array}$ & NS & 3 & $\begin{array}{c}149 \\
(1 \cdot 4)\end{array}$ & NS & $\begin{array}{c}13 \cdot 4 \\
(0.5)\end{array}$ & $<0.001$ \\
\hline $\begin{array}{l}\text { Day } 2 \\
\quad(25-28 \mathrm{~h})\end{array}$ & $\begin{array}{l}71.5 \\
(1.8)\end{array}$ & $<0.01$ & $\begin{array}{c}126 \mathrm{NS} \\
(1 \cdot 2)\end{array}$ & $\begin{array}{l}363 \\
(1 \cdot 8)\end{array}$ & NS & $\begin{array}{c}365 \\
(4)\end{array}$ & $<0.001$ & 8 & $\begin{array}{l}156 \\
(1 \cdot 5)\end{array}$ & NS & $\begin{array}{l}12 \cdot 7 \\
(0 \cdot 5)\end{array}$ & $<0.001$ \\
\hline $\begin{array}{l}\text { Day } 3 \\
\quad(49-52 h)\end{array}$ & $\begin{array}{l}73 \cdot 8 \\
(1 \cdot 9)\end{array}$ & $<0.001$ & $\underset{(1 \cdot 2)}{128} \mathrm{NS}$ & $\begin{array}{l}357 \\
(1 \cdot 5)\end{array}$ & $<0.01$ & $\begin{array}{r}384 \\
(6)\end{array}$ & $<0.001$ & 15 & $\begin{array}{l}157 \\
(1 \cdot 6)\end{array}$ & $<0.01$ & $\begin{array}{l}12 \cdot 2 \\
(0 \cdot 4)\end{array}$ & $<0.001$ \\
\hline $\begin{array}{l}\text { Day 4 } \\
\quad(73-76 h)\end{array}$ & $\begin{array}{l}74 \cdot 6 \\
(2 \cdot 0)\end{array}$ & $<0.001$ & $\underset{(1.4)}{129}<0.01$ & $\begin{array}{l}356 \\
(1.9)\end{array}$ & $<0.01$ & $\begin{array}{l}386 \\
(6)\end{array}$ & $<0.001$ & 20 & $\begin{array}{l}157 \\
(1 \cdot 7)\end{array}$ & $<0.01$ & $\begin{array}{l}14 \cdot 6 \\
(0 \cdot 4)\end{array}$ & $<0.001$ \\
\hline $\begin{array}{l}\text { Day } 5 \\
\quad(97-100 \mathrm{~h})\end{array}$ & $\begin{array}{l}77 \cdot 2 \\
(2 \cdot 1)\end{array}$ & $<0.001$ & $\underset{(1.3)}{136}<0.001$ & $\begin{array}{l}354 \\
(2 \cdot 0)\end{array}$ & $<0.01$ & $\begin{array}{l}405 \\
(1)\end{array}$ & $<0.001$ & 31 & $\begin{array}{c}161 \\
(1 \cdot 8)\end{array}$ & $<0.01$ & $\begin{array}{l}14 \cdot 5 \\
(0 \cdot 4)\end{array}$ & $<0.001$ \\
\hline $\begin{array}{l}\text { Day } 10 \\
\quad(217-220 \mathrm{~h})\end{array}$ & $\begin{array}{l}74 \cdot 8 \\
(1 \cdot 9)\end{array}$ & $<0.001$ & $\underset{(1.2)}{133<0.001}$ & $\begin{array}{l}348 \\
(2 \cdot 0)\end{array}$ & $<0.001$ & $\begin{array}{c}415 \\
(7)\end{array}$ & $<0.001$ & 28 & $\begin{array}{c}162 \\
(1.8)\end{array}$ & $<0.01$ & $\begin{array}{l}15 \cdot 2 \\
(0 \cdot 4)\end{array}$ & $<0.001$ \\
\hline \multicolumn{13}{|c|}{ Return to sea level ( $55 \mathrm{~min}$ by air) } \\
\hline (3-7h) & $\begin{array}{c}80 \cdot 3 \\
(1 \cdot 8)\end{array}$ & $<0.001$ & $\underset{(1 \cdot 3)}{128 \mathrm{NS}}$ & $\begin{array}{l}354 \\
(1 \cdot 8)\end{array}$ & $<0.001$ & $\begin{array}{r}392 \\
(7)\end{array}$ & $<0.001$ & 19 & $\begin{array}{l}162 \\
(2 \cdot 1)\end{array}$ & $<0.01$ & $\begin{array}{l}16 \cdot 6 \\
(0 \cdot 4)\end{array}$ & NS \\
\hline $\begin{array}{l}\text { Day } 2 \\
\quad(25-28 \mathrm{~h})\end{array}$ & $\begin{array}{l}67 \cdot 5 \\
(1 \cdot 4)\end{array}$ & NS & $\underset{(1 \cdot 2)}{124} \mathrm{NS}$ & $\begin{array}{l}366 \\
(1 \cdot 6)\end{array}$ & NS & $\begin{array}{r}347 \\
(4)\end{array}$ & NS & Nil & $\begin{array}{l}153 \\
(1 \cdot 4)\end{array}$ & NS & $\begin{array}{l}17 \cdot 5 \\
(0 \cdot 4)\end{array}$ & NS \\
\hline $\begin{array}{l}\text { Day } 3 \\
\quad(49-52 h)\end{array}$ & $\begin{array}{l}65 \cdot 3 \\
(1 \cdot 4)\end{array}$ & NS & $\begin{array}{c}123 \text { NS } \\
(1 \cdot 1)\end{array}$ & $\begin{array}{l}368 \\
(1 \cdot 6)\end{array}$ & NS & $\begin{array}{l}342 \\
(4)\end{array}$ & NS & Nil & $\begin{array}{l}152 \\
(1 \cdot 4)\end{array}$ & NS & $\begin{array}{l}17 \cdot 9 \\
(0 \cdot 4)\end{array}$ & NS \\
\hline $\begin{array}{l}\text { TRHA } \\
\text { (group C) }\end{array}$ & $69 \cdot 1$ & & $\begin{array}{l}126 \\
(1 \cdot 2)\end{array}$ & $\begin{array}{l}369 \\
(1 \cdot 7)\end{array}$ & & $\begin{array}{l}359 \\
(5)\end{array}$ & & 6 & $\begin{array}{l}160 \\
(1 \cdot 6)\end{array}$ & & $\begin{array}{l}12 \cdot 8 \\
(0 \cdot 2)\end{array}$ & \\
\hline $\begin{array}{l}\text { PRHA } \\
\text { (group D) }\end{array}$ & $56 \cdot 2$ & & $\begin{array}{l}116 \\
(1 \cdot 2)\end{array}$ & $\begin{array}{l}375 \\
(1 \cdot 6)\end{array}$ & & $\begin{array}{c}321 \\
(5)\end{array}$ & & Nil & $\begin{array}{l}150 \\
(1 \cdot 7)\end{array}$ & & $\begin{array}{c}19 \cdot 3 \\
(0 \cdot 2)\end{array}$ & \\
\hline
\end{tabular}

«Statistical levels as compared with sea level values. Figures in parentheses indicate standard error of mean. PRHA, Permanent residents of high altitude; TRHA, temporary residents of high altitude.

PEP/LVET $=$ actual values $\times 1000$. PEP, LVET, RZ are in milliseconds corrected for heart rate. PEP/LVET, and $\frac{\mathrm{dZ} / \mathrm{dt}}{\mathrm{RZ}}$ are from uncorrected values.

values were scanned to note the number of individuals showing a PEP/LVET ratio of over 400 on the days of study. At sea level no subiect had a PEP/LVET ratio of more than 400 . Up to 4 hours of stay at high altitude only one subject had a ratio more than 400 . At 5 to 8 hours 3 subjects, on the second day 8 subjects, on the third day 15 subjects, on the fourth day 20 , on the fifth day 31 , and on the tenth day 28 subjects had values in excess of 400 . Immediately on return to sea level, 19 continued to show abnormal figures on the first day. On the second and third day of return none of the subjects had abnormal values.

The mean sea level control value of group B was 325. This rose to 374 on arrival at altitude and gradually rose to 434 on the tenth day. On the third day of return to sea level the values had dropped to
350. At sea level no subject had a ratio exceeding 400. On the first day at altitude 7 subjects, on the second day 5 subjects, on the third day 13, the fourth day 14, the fifth day 16 , and on the tenth day 23 subjects showed values above 400 . On the second day of return to sea level 10 subjects continued to show abnormal values and on the third day none had abnormal values. The mean PEP/LVET ratio of group C was 359 and that of group D 321.

The $\mathrm{QS}_{2}$ interval corrected for heart rate did not show significant changes in both the groups.

\section{RZ INTERVAL}

In group $\mathrm{A}$, the control $\mathrm{RZ}$ interval index was 149 $\mathrm{ms}$. This began to increase by the second day of arrival at altitude and reached a peak of $162 \mathrm{~ms}$ on the tenth day. On the third day of return to sea level 
Table 2 Serial changes in levels of myocardial function in subjects inducted to $3658 \mathrm{~m}$ by road

\begin{tabular}{|c|c|c|c|c|c|c|c|c|c|c|c|c|c|}
\hline Time of study & Heart rate & $P$ & $P E P$ & $P$ & $L V E T$ & $P$ & $P E P / L V E T$ & $P$ & $\begin{array}{l}P E P / L V E T \\
>400\end{array}$ & $\begin{array}{l}R Z \\
\text { interval }\end{array}$ & $P$ & $\frac{d Z / d t}{R Z}$ & $\boldsymbol{P}$ \\
\hline Sea level & $\begin{array}{l}63 \cdot 2 \\
(1 \cdot 7)\end{array}$ & 一 & $\begin{array}{l}127 \\
(1 \cdot 7)\end{array}$ & - & $\underset{(1 \cdot 6)}{381}$ & - & $\begin{array}{c}325 \\
(6)\end{array}$ & - & Nil & $\begin{array}{l}159 \\
(1 \cdot 7)\end{array}$ & - & $\begin{array}{l}17 \cdot 9 \\
(0 \cdot 6)\end{array}$ & \\
\hline \multicolumn{14}{|c|}{ High altitude ( $3658 \mathrm{~m}$ by road in $6 h$ ) } \\
\hline$(18-20 \mathrm{~h})$ & $\begin{array}{l}86 \cdot 7 \\
(3 \cdot 1)\end{array}$ & $<0.001$ & $\begin{array}{l}133 \\
(1 \cdot 5)\end{array}$ & NS & $\begin{array}{l}359 \\
(2 \cdot 1)\end{array}$ & $<0.01$ & $\begin{array}{l}374 \\
(7)\end{array}$ & $<0.001$ & 7 & $\begin{array}{l}168 \\
(2 \cdot 3)\end{array}$ & $<0.01$ & $\begin{array}{l}14 \cdot 9 \\
(0 \cdot 8)\end{array}$ & $<0.001$ \\
\hline $\begin{array}{l}\text { Day } 2 \\
\quad(42-44 h)\end{array}$ & $\begin{array}{l}92 \cdot 3 \\
(3 \cdot 2)\end{array}$ & $<0.001$ & $\begin{array}{l}140 \\
(1 \cdot 7)\end{array}$ & $<0.01$ & $\begin{array}{c}363 \\
(1.9)\end{array}$ & $<0.01$ & $\begin{array}{c}374 \\
(9)\end{array}$ & $<0.001$ & 5 & $\begin{array}{l}170 \\
(3 \cdot 1)\end{array}$ & $<0.01$ & $\begin{array}{l}14 \cdot 7 \\
(0 \cdot 7)\end{array}$ & $<0.001$ \\
\hline $\begin{array}{l}\text { Day } 3 \\
\quad(66-68 h)\end{array}$ & $\begin{array}{l}90 \cdot 7 \\
(3 \cdot 2)\end{array}$ & $<0.001$ & $\begin{array}{c}139 \\
(2 \cdot 0)\end{array}$ & $<0.01$ & $\begin{array}{l}358 \\
(2 \cdot 1)\end{array}$ & $<0.01$ & $\begin{array}{r}396 \\
(9)\end{array}$ & $<0.001$ & 13 & $\begin{array}{l}171 \\
(2 \cdot 4)\end{array}$ & $<0.01$ & $13 \cdot 0$ & $<0.001$ \\
\hline $\begin{array}{l}\text { Day } 4 \\
\quad(90-92 h)\end{array}$ & $\begin{array}{l}80 \cdot 8 \\
(2 \cdot 3)\end{array}$ & $<0.001$ & $\begin{array}{r}142 \\
(2 \cdot 2)\end{array}$ & $<0.001$ & $\begin{array}{l}365 \\
(1.9)\end{array}$ & $<0.01$ & $\begin{array}{r}394 \\
(9)\end{array}$ & $<0.001$ & 14 & $\begin{array}{l}173 \\
(2 \cdot 8)\end{array}$ & $<0.001$ & $\begin{array}{l}12 \cdot 6 \\
(0 \cdot 7)\end{array}$ & $<0.001$ \\
\hline $\begin{array}{l}\text { Day } 5 \\
\quad(114-116 h)\end{array}$ & $\begin{array}{l}84 \cdot 4 \\
(2 \cdot 7)\end{array}$ & $<0.001$ & $\begin{array}{c}143 \\
(1 \cdot 6)\end{array}$ & $<0.001$ & $\begin{array}{l}360 \\
(2 \cdot 1)\end{array}$ & $<0.01$ & $\begin{array}{c}406 \\
(8)\end{array}$ & $<0.001$ & 16 & $\begin{array}{l}176 \\
(2 \cdot 8)\end{array}$ & $<0.001$ & $\begin{array}{l}13 \cdot 0 \\
(0.6)\end{array}$ & $<0.001$ \\
\hline $\begin{array}{l}\text { Day } 10 \\
\quad(235-237 \mathrm{~h})\end{array}$ & $\begin{array}{l}87 \cdot 9 \\
(2 \cdot 4)\end{array}$ & $<0.001$ & $\begin{array}{l}144 \\
(1 \cdot 7)\end{array}$ & $<0.001$ & $\begin{array}{l}350 \\
(1 \cdot 6)\end{array}$ & $<0.001$ & $\begin{array}{r}434 \\
(8)\end{array}$ & $<0.001$ & 23 & $\begin{array}{l}179 \\
(2 \cdot 8)\end{array}$ & $<0.001$ & $\begin{array}{l}13 \cdot 6 \\
(0 \cdot 6)\end{array}$ & $<0.001$ \\
\hline $\begin{array}{l}\text { Return to sea } \\
\text { Day } 2\end{array}$ & level (by $r$ & ad in $6 h$ ) & & & & & & & & & & & \\
\hline $\begin{array}{l}(25-27 \mathrm{~h}) \\
\text { Day } 3\end{array}$ & $\begin{array}{l}62.9 \\
(1.5)\end{array}$ & NS & $\begin{array}{l}142 \\
(1 \cdot 4)\end{array}$ & $<0.001$ & $\begin{array}{l}366 \\
(1 \cdot 6)\end{array}$ & $<0.01$ & $\begin{array}{l}393 \\
(6)\end{array}$ & $<0.001$ & 10 & $\begin{array}{l}165 \\
(1 \cdot 7)\end{array}$ & $<0.01$ & $\begin{array}{l}15 \cdot 5 \\
(0 \cdot 6)\end{array}$ & $<0.01$ \\
\hline$(49-51 \mathrm{~h})$ & $\begin{array}{l}63 \cdot 0 \\
(1 \cdot 3)\end{array}$ & NS & $\begin{array}{l}133 \\
(1 \cdot 7)\end{array}$ & NS & $\begin{array}{l}373 \\
(1 \cdot 6)\end{array}$ & NS & $\begin{array}{c}350 \\
(7)\end{array}$ & NS & Nil & $\begin{array}{l}157 \\
(2 \cdot 3)\end{array}$ & NS & $\begin{array}{l}17 \cdot 0 \\
(0 \cdot 6)\end{array}$ & NS \\
\hline
\end{tabular}

Abbreviations as in Table 1.

the interval index was normal. Group B had control levels of $159 \mathrm{~ms}$ at sea level. This gradually increased to $179 \mathrm{~ms}$ on the tenth day at altitude and completely normal values occurred on the third day of return. Group $\mathrm{C}$ had values of $160 \mathrm{~ms}$ and group D $150 \mathrm{~ms}$.

\section{CONTRACTILITY INDEX}

The control value of 17.4 of group A showed a reduction to $12 \cdot 2$ on the third day. This was followed by a gradual improvement till the tenth day when a value of 15.2 was noted. Normal figures occurred on the third day of return to sea level. Group B had control levels of 17.9 which declined to 12.6 on the fourth day. A subsequent improvement occurred till the tenth day when a value of 13.6 was obtained. Normal values obtained by the third day of return to sea level. Group C had a value of 12.8 and group D 19.3 at high altitude. The values, along with levels of statistical significance, are expressed in Tables 1 and 2.

\section{STROKE INDEX (Table 3)}

The stroke index of group A was $46 \cdot 2 \mathrm{ml} / \mathrm{m}^{2}$ at sea level. It showed a gradual and sustained reduction to $29.8 \mathrm{ml} / \mathrm{m}^{2}$ on the tenth day. The values were normal on the second day of return. The stroke index of group B was $48.8 \mathrm{ml} / \mathrm{m}^{2}$ and it showed a reduction to $28.9 \mathrm{ml} / \mathrm{m}^{2}$ on the tenth day of stay at high altitude. Normal values were obtained on the second day of return to sea level. Group C had values of $31.5 \mathrm{ml} / \mathrm{m}^{2}$ and group $\mathrm{D} 49.7 \mathrm{ml} / \mathrm{m}^{2}$.

\section{CARDIAC INDEX}

The cardiac index of group A was $2.941 / \mathrm{min}$ per $\mathrm{m}^{2}$ at sea level and it came down to $2.471 / \mathrm{min}$ per $\mathrm{m}^{2}$ on the tenth day at high altitude. Normal values were reached immediately on return.

Group B had values of $3.09 \mathrm{l} / \mathrm{min}$ per $\mathrm{m}^{2}$ which came down to $2.49 \mathrm{1} / \mathrm{min}$ per $\mathrm{m}^{2}$ on the tenth day at high altitude. Normal values were reached on the second day of return to sea level.

\section{URINARY CATECHOLAMINE EXCRETION}

The levels of urinary catecholamine excretion in 24 hours are shown in Table 4. Group A showed a significant increase in the values, reaching a peak on the tenth day. Group B showed a mild and statistically insignificant increase in 24 hours' catecholamine excretion.

\section{Discussion}

Accurate assessment of myocardial function at high altitude has been difficuit for many reasons Hostile environment, rough terrain, and lack of 
Table 3 Serial changes in stroke index and cardiac index of subjects inducted to $3658 \mathrm{~m}$ by air and road

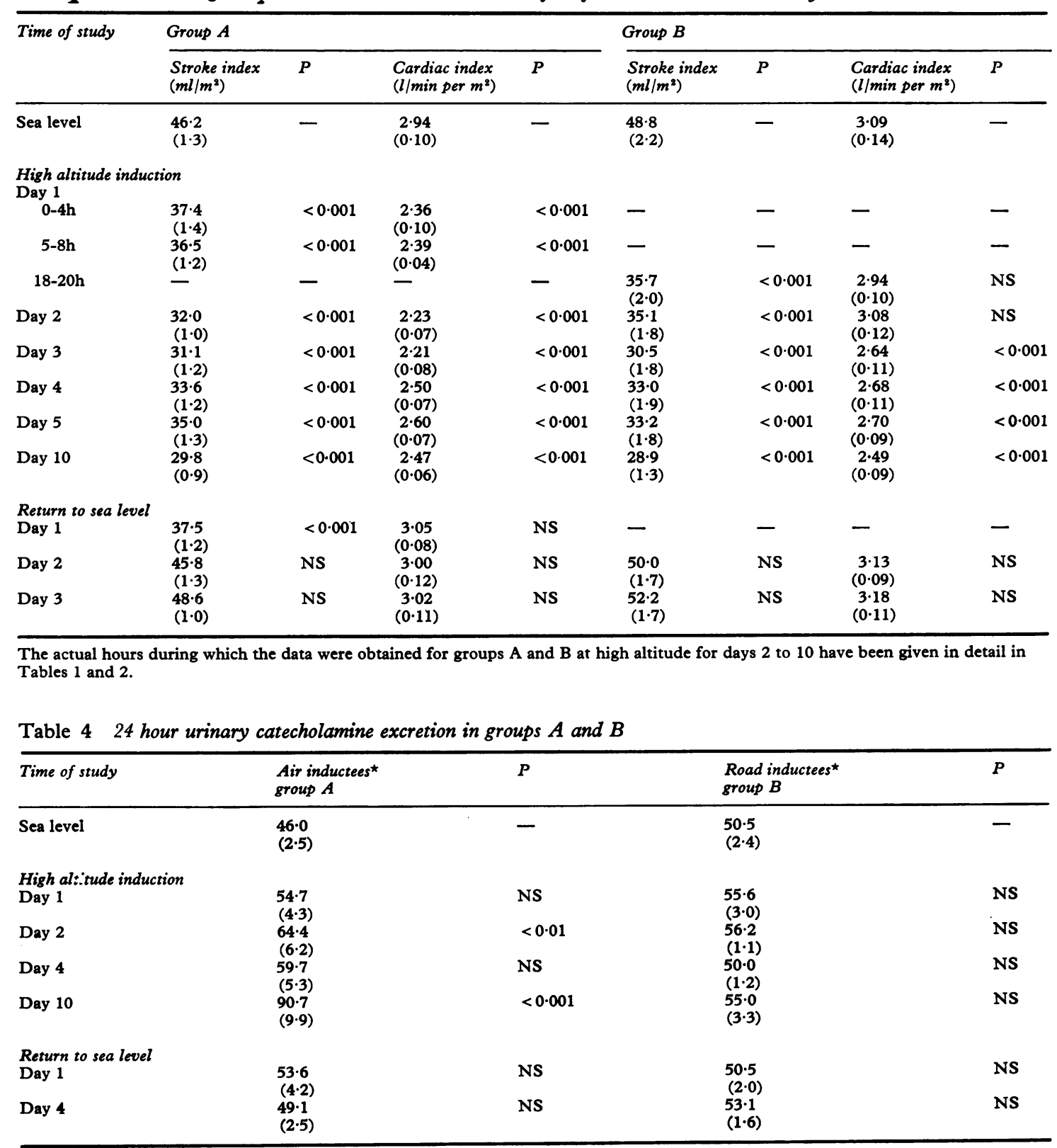

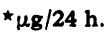

adequate laboratory facilities have been the main deterrents. The traumatic techniques of assessing left ventricular function limited the sample size because of ethical and logistical reasons. Attempts at stimulating hypoxia in a chamber yielded conflicting results because of the short duration of exposure and other physiological responses. The availability of simple, rapid, reliable, and repro- $\stackrel{\oplus}{+}$ ducible noninvasive procedures stimulated interest $T$ in assessment of myocardial function in various situations. In our pilot study alterations in systolic $\stackrel{D}{\mathbb{D}}$ time intervals suggested left ventricular dysfunction $\stackrel{\mathbb{Q}}{\stackrel{8}{2}}$ on exposure to high altitude (Balasubramanian et al., 1975). 
In the current study, the subjects were exposed to high altitude by air and road. The recordings were made more frequently to delineate the immediate and late effects of hypoxia. Two additional control groups of highlanders and lowlanders were included. Studies on return to sea level were incorporated to distinguish the pattern of reversion to normal. Electrical impedance cardiography and systolic time intervals were chosen as the methods of choice. They yielded maximal information regarding left ventricular function and stroke index. The daily recordings could be completed within 4 hours eliminating diurnal variations.

The impedance plethysmogram picked up body potentials through inexpensive, reusable, cutaneous electrodes. It yielded two additional parameters of myocardial function, that is $R Z$ interval and $\frac{d Z / d t}{R Z}$ index. In addition, data could be simultaneously obtained noninvasively in respect of stroke index, cardiac index, and thoracic extravascular fluid volume (Kubicek et al., 1966; Geddes and Baker, 1968; Siegel et al., 1970; Lababidi et al., 1970; Hill and Lowe, 1973; Luepker et al., 1973; Balasubramanian and Hoon, 1976; Hill and Merrifield, 1976).

This study was planned to delineate the effect of high altitude hypoxia in isolation on myocardial performance, excluding other influences such as cold and physical activity. We could accumulate data regarding the myocardial function at 0 to 4 hours, 5 to 8 hours, 18 to 20 hours, 25 to 28 hours, $2,3,4,5$, and 10 days of stay at an altitude of $3658 \mathrm{~m}$. The subjects were studied under carefully controlled conditions of temperature, physical activity, and other requisites for comparable data. Two control groups of temporary and permanent residents at high altitude were also studied under identical conditions. Scrupulous care was taken to avoid smoking, consumption of alcohol, drug ingestion, exposure to cold, and physical exertion during the entire study. No other simultaneous invasive study was conducted in these subjects, thus avoiding the possibility of sympathetic stimulation caused by these procedures. Simultaneous estimation of urinary catecholamine excretion ensured quantification of compensatory sympathetic overactivity which occurred as a result of high altitude hypoxia.

Alterations of pre-ejection period, left ventricular ejection time, PEP/LVET ratio, RZ interval, and contractility index clearly indicated depression of myocardial function. A predictable and reproducible pattern was observed in all of them. No significant changes were discernible in these values at 0 to 4 hours and 5 to 8 hours after arrival at altitude. The earliest alterations occurred at 18 hours. There was gradual but sustained deterioration as the days progressed, reaching a maximum on the tenth day of stay. The only value which showed a consistent improvement after the fourth day was the $\frac{d Z / d t}{R Z}$ index. Reversion to normal did not occur immediately on return to sea level but took 48 to 72 hours.

The findings of our current study, though essentially similar to our initial report, differ in a few aspects. During the last expedition we studied 20 subjects serially on high altitude exposure and found that maximal changes were seen until the fourth day, with a tendency for the mean values to improve by the tenth day even though tenth day values were still abnormal (Balasubramanian et al., 1975). During the present study we found that all values except $\frac{\mathrm{dZ} / \mathrm{dt}}{\mathrm{RZ}}$ continued to deteriorate gradually till the tenth day. The 56 permanent residents of high altitude (group D) had completely normal myocardial function. On the other hand, the lowlanders temporarily resident at altitude (group C) showed only a mild impairment of these indices compared with the highlanders, thus suggesting a fair degree of return to normal as a result of acclimatisation.

The exact genesis of the alterations of these systolic time intervals at high altitude is still a matter of conjecture. Some authors have reported lengthening of PEP, diminution of LVET, and increase in the PEP/LVET ratio in patients with diminished left ventricular performance (Weissler et al., 1968, 1969; Lewis, 1975). The PEP/LVET ratio was found to be closely correlated to the ejection fraction by a number of workers (Weissler et al., 1969; Garrard et al., 1970). Ahmed and coworkers (1972) showed significant correlation between the PEP/LVET and the ejection fraction, contractile element velocity at peak isometric stress, and the Frank-Levision contractility index in patients with left ventricular myocardial disease. On the other hand, when valvular heart disease or intracardial shunts were present no such correlation could be found. As our subjects were entirely normal and had distinct alterations in PEP/LVET ratio, it is reasonable to conclude that primary depression of the left ventricular function caused by high altitude hypoxia may be an important contributing factor.

The importance of alterations in preload in the genesis of these changes requires clarification. Boudoulas et al. (1971) reported deterioration of PEP/LVET in patients with congestive heart 
failure after diuresis. This was attributed to a diminished filling pressure for a noncompliant left ventricle. It is unlikely that this mechanism plays a dominant role in the causation of these alterations. The main changes that occur in high altitude are a shift of the blood volume more centrally. Some authors have reported a reduction in urine output at high altitude (Singh et al., 1969). Wood and Roy (1970) showed a decrease in peripheral blood flow using a venous occlusion plethysmograph. The possibility of a reduced preload occurring at high altitude causing these changes in systolic time intervals, therefore, appears unlikely.

In group $A$ the alterations in left ventricular function were observed despite an increase in urinary catecholamine excretion levels. In group B, where the catecholamine excretion was not increased, the extent of changes particularly the PEP/ LVET ratio was more pronounced. The distinct chronological correlation between the reduction in stroke index with depression of the levels of myocardial contractility was striking, suggesting left ventricular dysfunction as the prime cause for the reduced stroke and cardiac indices.

The practical implications and applications of this study are obvious. Distinct alterations of all indices of myocardial function have been observed in young, normal, weil-trained subjects exposed to high altitude for the first time. The changes are likely to be much more obvious in older subjects and in those returning to sea level. Most of the workers had hitherto not seriously considered left ventricular dysfunction as one of the possible factors in the aetiology of high altitude illnesses. Attempts were made to explain and attribute the changes solely to local changes in the pulmonary vessels, with no contributing part of the left ventricle (Viswanathan et al., 1969). Attempts at prophylaxis of high altitude illnesses were also naturally aimed at correcting these factors rather than improving left ventricular performance (Singh et al., 1969). The results of our study suggest that left ventricular dysfunction occurs on high altitude exposure and cannot be ignored as one of the causes of high altitude illnesses. Attempts to improve myocardial performance by specific inotropic agents may be a suitable avenue for at least a partial prophylaxis against these groups of illnesses.

It should, however, be conceded that left ventricular dysfunction may not be the sole or dominant cause for the pathophysiological alterations at altitude. At best, it can only be postulated that it might play a role in the genesis of these changes, the pathogenesis of which is as yet undefined. They are most probably caused by an accumulation of a multitude of adverse reactions occurring in the human cardiorespiratory system on exposure to high altitude.

\section{References}

Ahmed, S. S., Levinson, G. E., Schwartz, C. J., and Ettinger, P. O. (1972). Systolic time intervals as measures of contractile state of the myocardium in man. Circulation, 46, 559-571.

Alexander, J. K., Hartley, L. H., Modelski, M., and Grover, R. F. (1967). Reduction of stroke volume during exercise in man following ascent to $3100 \mathrm{~m}$ altitude. Fournal of Applied Physiology, 23, 849-858.

Aronow, W. S. (1970). Isovolumetric contraction and left ventricular ejection time: external measurements at rest and after exercise in normal men. American fournal of Cardiology, 26, 238-240.

Asmussen, E., and Consolazio, F. (1941). The circulation in rest and work on Mount Evans (4300 m). American fournal of Physiolngy, 132, 555-563.

Badeer, H. S. (1973). Cardiomegaly at high altitudes: pathogenetic considerations. Aerospace Medicine, 44, 1173-1180.

Balasubramanian, V., and Hoon, R. S. (1975). Applications of transthoracic electrical impedance: a non-invasive technique for detection of changes in thoracic fluid volumes. Fournal of the Association of Physicians of India, 23, 611-616.

Balasubramanian, V., and Hoon, R. S. (1976). Changes in transthoracic electrical impedance during submaximal treadmill exercise in patients with ischemic heart diseaseA preliminary report. American Heart fournal, 91, 43-49.

Balasubramanian, V., Kaushik, V. S., Manchanda, S. C., and Roy, S. B. (1975). Effects of high altitude hypoxia on left ventricular systolic time intervals in man. British Heart fournal, 37, 272-276.

Banchero, N., Sime, F., Penaloza, D., Gruz, J., Gamboa, R. and Marticorena, E. (1966). Pulmonary pressure, cardiac output and arterial oxygen saturation during exercise at high altitude and at sea level. Circulation, 33, 249-262.

Boudoulas, H., Lewis, R. P., and Weissler, A. M. (1971). Use of systolic time intervals as a measure of left ventricular performance during therapy of congestive heart failure (abstract). Circulation, 43 and 44, Suppl. II, 144.

Chung, E. K. (1976). Noninvasive Cardiac Diagnosis. Lea and Febiger, Philadelphia.

Garrard, C. L., Jr, Weissler, A. M., and Dodge, H. T. (1970) The relationship of alterations in systolic time intervals to ejection fraction in patients with heart disease. Circulation, 42, 455-462.

Geddes, L. A., and Baker, L. E. (1968). Principles of Applied Biomedical Instrumentation. John Wiley, New York.

Grollman, A. (1930). Physiological variations of the cardiac output of man. VII. The effect of high altitude on the cardiac output and its related functions; an account of experiments conducted on the summit of Pike's Peak, Colorado. American fournal of Physiology, 93, 19-39.

Hartley, L. H. (1971). Effects of high altitude environment on the cardiovascular system of man. Fournal of the American Medical Association, 215, 241-244.

Hartley, L. H., Alexander, J. K., Modelski, M., and Grover, R. F. (1967). Subnormal cardiac output at rest and during exercise in residents at $3100 \mathrm{~m}$ altitude. Fournal of Applied Physiology, 23, 839-848.

Hill, D. W., and Lowe, H. J. (1973). The use of the electricalimpedance technique for the monitoring of cardiac output and limb blood flow during anaesthesia. Medical and Biological Engineering, 11, 534-545.

Hill, D. W., and Merrifield, A. J. (1976). Left ventricular ejection and the Heather index measured by noninvasive methods during postural changes in man. Acta Anaes- 
thesiologica Scandinavica, 20, 313-320.

Hoon, R. S., Balasubramanian, V., Mathew, O. P., Tiwari, S. G., Sharma, S. C., and Chadha, K. S. (1977a). Effect of high altitude exposure for 10 days on stroke volume and cardiac output. Fournal of Applied Physiology, 42, 722-727.

Hoon, R. S., Balasubramanian, V., Tiwari, S. C., Mathew, O.P., Behl, A., Sharma, S. C., and Chadha, K. S. (1977b). Changes in transthoracic electrical impedance at high altitude. British Heart fournal, 39, 61-66.

Hoon, R. S., Sharma, S. C., Balasubramanian, V., and Chadha, K. S. (1977c). Urinary catecholamine excretion on induction to high altitude $(3658 \mathrm{~m})$ by air and road. fournal of Applied Physiology, 42, 728-730.

Hoon, R. S., Sharma, S. C., Balasubramanian, V., Chadha, K. S., and Mathew, O. P. (1976). Urinary catecholamine excretion on acute induction to high altitude. Fournal of Applied Physiology, 41, 631-633.

Hultgren, H. N., Lopez, C. E., Lundberg, E., and Miller, H. (1964). Physiologic studies of pulmonary edema at high altitude. Circulation, 29, 393-408.

Klausen, K. (1966). Cardiac output in man at rest and work during and after acclimatization to $3800 \mathrm{~m}$. Fournal of Applied Physiology, 21, 609-616.

Kowalsky, N. B., and Anthony, J. R. (1972). Cardiac electromechanical time intervals as indices of hypoxic circulatory stress in man. Aerospace Medicine, 43, 361-367.

Kubicek, W. G., Karnegis, J. N., Patterson, R. P., Witsoe, D. A., and Mattson, R. H. (1966). Development and evaluation of an impedance cardiac output system. Aerospace Medicine, 37, 1208-1212.

Kumar, S., and Spodick, D. H. (1970). Study of the mechanical events of the left ventricle by atraumatic techniques: comparison of methods of measurement and their significance. American Heart fournal, 80, 401-413.

Lababidi, Z., Ehmke, D. A., Durnin, R. E., Leaverton, P. E., and Lauer, R. M. (1970). The first derivative thoracic impedance cardiogram. Circulation, 41, 651-658.

Lewis, R. P. (1975). Diagnostic value of systolic time intervals in man. In Diagnostic Methods in Cardiology, p. 245. Ed. by N. O. Fowler. F. A. Davis, Philadelphia.

Lewis, R. P., Weissler, A. M., and Leighton, R. F. (1974). Systolic time intervals. In Noninvasive Cardiology, p. 301. Ed. by A. M. Weissler. Grune and Stratton, New York.

Lindquist, V. A. Y., Spangler, R. D., and Blount, S. G., Jr. (1973). A comparison between the effects of dynamic and isometric exercise as evaluated by the systolic time intervals in normal man. American Heart fournal, 85, 277-236.

Luepker, R. V., Michael, J. R., and Warbasse, J. R. (1973). Transthoracic electrical impedance; quantitative evaluation of a noninvasive measure of thoracic fluid volume. American Heart fournal, 85, 83-93.

Menon, N. D. (1965). High altitude pulmonary edema. New England fournal of Medicine, 273, 66-73.

Moret, P., Covarrubias, E., Coudert, J., and Duchosal, F. (1972). Cardiocirculatory adaptation to chronic hypoxia. III. Comparative study of cardiac output, pulmonary and systemic circulation between sea level and high altitude residents. Acta Cardiologica, 27, 596-619.

Quarry-Pigott, V. M., Chirife, R., and Spodick, D. H. (1973). Ejection time by ear densitogram and its derivative: clinical and physiologic applications. Circulation, 48, 239246.

Roy, S. B., Balasubramanian, V., Khan, M. R., Kaushik, V. S., Manchanda, S. G., and Guha, S. K. (1974). Transthoracic electrical impedance in cases of high altitude hypoxia. British Medical fournal, 3, 771-775.

Siegel, J. H., Fabian, M., Lankau, C., Levine, M., Cole, A., and Nahmad, M. (1970). Clinical and experimental use of thoracic impedance plethysmography in quantifying myocardial contractility. Surgery, 67, 907-917.

Sime, F., Peñaloza, D., Ruiz, L., Gonzales, N., Covarrubias, E., and Postigo, R. (1974). Hypoxemia, pulmonary hypertension and low cardiac output in newcomers at low altitude. Fournal of Applied Physiology, 36, 561-563.

Singh, I., Kapila, C. C., Khanna, P. K., Nanda, R. B., and Rao, B. D. P. (1965). High altitude pulmonary oedema. Lancet, 1, 229-234.

Singh, I., Khanna, P. K., Srivastava, M. C., Lal, M., Roy, S. B., and Subramaniam, C. S. V. (1969). Acute mountain sickness. New England fournal of Medicine, 280, 175-184.

Spodick, D. H., and Lance, V. Q. (1976). Noninvasive stress testing: methodology for elimination of the phonocardiugram. Circulation, 53, 673-676.

Viswanathan, R., Jain, S. K., and Subramanian, S. (1969). Pulmonary edema of high altitude. III. Pathogenesis. American Review of Respiratory Diseases, 100, 342-349.

Vogel, J. A., Hansen, J. E., and Harris, C. W. (1967). Cardiovascular reponses in mean during exhaustive work at sea level and high altitude. Fournal of Applied Physioligy, 23, 531-539.

Vogel, J. A., Hartley, L. H., Cruz, J. C., and Hogan, R. P. (1974). Cardiac output during exercise in sea level residents at sea level and high altitude. Fournal of Applied Physiology, 36, 169-172.

Weissler, A. M. (1974). Noninvasive Cardiology, p. 454. Grune and Stratton, New York and London.

Weissler, A. M. (1976). Symposium: Noninvasive methods for evaluating left ventricular performance in coronary artery disease. American fournal of Cardiology, 37, 773-806.

Weissler, A. M., Harris, W. S., and Schoenfeld, C. D. (1968). Systolic time intervals in heart failure in man. Circulation, 37, 149-159.

Weissler, A. M., Harris, W. S., and Schoenfeld, C. D. (1969). Bedside technics for the evaluation of ventricular function in man. American fournal of Cardiology, 23, 577-583.

Weissler, A. M., and Schoenfeld, C. D. (1970). Effect of digitalis on systolic time intervals in heart failure. American Fournal of the Medical Sciences, 259, 4-20.

Wood, J. E., and Roy, S. B. (1970). The relationship of peripheral venomotor responses to high altitude pulmonary edema in man. American fournal of the Medical Sciences, 259, 56-65.

Zoneraich, S. (1974). Noninvasive Methods in Cardiology, p. 582. Charles C. Thomas, Springfield, Illinois.

Requests for reprints to Major V. Balasubramanian, Department of Cardiology, Northwick Park Hospital, Watford Road, Harrow, Middlesex HA1 3UJ. 